\section{Quaternary prevention: a concept relevant to public health? A bibliometric and descriptive content analysis}

\author{
Prevenção quaternária: um conceito relevante \\ para a saúde pública? Uma análise bibliométrica \\ e descritiva
}

\section{Prevención cuaternaria: ¿un concepto relevante para la salud pública? Un análisis bibliométrico y de contenido descriptivo}

\begin{abstract}
According to the World Organization of Family Doctors (WONCA), quaternary prevention $(P 4)$ is a recent concept that aims to prevent medical overuse. Thus, this study aimed to measure and map research output on $\mathrm{P} 4$ as outline research trends, evaluating its current international status through a bibliometric and descriptive content analysis. We reviewed scientific articles on P4 recorded in PubMed, LILACS, SciELO or CINAHL with the outcomes: publication year, first authors' name and nationality, journals' name, country and ranking, publication language, used methods and main reported subjects. The analysis included 65 articles published in 33 journals of 16 countries between 2003 and 2018 with a peak of publications in 2015. The first authors came from 17 different countries, 23\% Brazilian, with Uruguay as the leading nation in scientific production per capita. Q1 or Q2 journals amassed 28\% of published papers. Bibliographic research comprised 88\% of articles and 38\% of all focused on specific examples of medical overuse. P4 represents an ethical and valid approach to prevent iatrogenic events and achieve equal and fair access to health services. Conceptual, geographical, and linguistic elements, as well as WONCA conferences and type of healthcare systems in the authors' country were fundamental factors that affected research output. The available studies are still of limited quality and quantity, with further investigations needed to assess the effective impact of P4 on public health.
\end{abstract}

Quaternary Prevention; Medical Overuse; Bibliometrics;

Qualitative Research
Miguel Andino Depallens 1,2 Jane Mary de Medeiros Guimarães 1 Naomar Almeida Filho 3

doi: 10.1590/0102-311X00231819

\author{
Correspondence \\ M. A. Depallens \\ Rua Catarina Fogaça 189, Salvador, BA 41750-120, Brasil. \\ miguel.depallens@yahoo.fr \\ 1 Universidade Federal do Sul da Bahia, Itabuna, Brasil. \\ 2 Universidade Federal do Recôncavo da Bahia, Santo Antônio \\ de Jesus, Brasil. \\ 3 Instituto de Saúde Coletiva, Universidade Federal da Bahia, \\ Salvador, Brasil.
}




\section{Introduction}

The concept of medicalization is frequently misused to define the excessive use of medical care, but in an etymological perspective, it represents the process where some phenomena of human life become a medical concern. Medicalization does not constitute a problem per se and, in some situations, provides "great successes with treating infections, heart diseases, some cancers, and hormone deficiencies like type 1 diabetes" 1 (p. 14).

The issue emerges when medicine expands its scope beyond its own limits and is regarded as the best or only effective approach to handle regular life events, such as insomnia, grief, delivery, hyperactivity, menopause. Known as the medicalization of life 2, this simplistic perspective considers health conditions an exclusive result of biomedical issues, denying the broad diversity of health determinants: lifestyle, socioeconomic, cultural, and environmental conditions.

\section{Quaternary prevention: conceptual background}

In the late 1980s, influenced by Illich's book 2 on the medicalization of life and iatrogenesis, the Belgian family physician Marc Jamoulle 3 revised Leavell \& Clark's prevention levels 4, integrating a public health approach into individual clinical practice. Jamoulle's classification comprised two specific dimensions, one defined by the patient's feeling (illness) and the other by the clinical assessment (disease) 5:

(i) Primary prevention (P1) acts on healthy individuals (absence of illness) to prevent a specific disease (absence of disease), by advising smoking cessation to prevent lung cancer and chronic obstructive pulmonary disease (COPD), for example.

(ii) Secondary prevention (P2) aims to early detect a potentially severe disease in an asymptomatic population (absence of illness), increasing cure probability by identifying and treating its initial stage (presence of disease), such as an annual eye fundoscopy to detect diabetic retinopathy.

(iii) Tertiary prevention (P3) proposes to reduce the impacts of any disease on quality of life (illness and disease present) by medical treatment or rehabilitation, such as an early neurorehabilitation therapy after a disabling stroke.

(iv) Quaternary prevention (P4) aims to prevent medical overuse in situations where the patient feels ill (illness present), but the physician does not attribute the symptoms to any biological disease (absence of disease). An example is the use the watchful wainting strategy when a young healthy patient with no cardiovascular risk or symptom worries about his cholesterol level.

Overmedicalization or medical overuse can be defined as unnecessary medical intervention that brings more harm than benefit 6 .

In 2000, Barbara Starfield reported data showing that iatrogenic events represented the third cause of death in the United States 7 . In 2003, the term P4 was finally acknowledged by the scientific community, the World Organization of National Colleges, Academies and Academic Associations of General Practitioners/Family Physicians (WONCA) and the World International Classification Committee (WICC) ${ }^{8}$. From then on, the new definition expanded its scope and went beyond the concepts of illness and disease, focusing on tackling all medical overuse situations and anchored on the principle of non-maleficence: "Action taken to identify a patient or a population at risk of overmedicalization, to protect them from new medical invasions and suggest to them interventions, which are ethically acceptable" 8 (p. 110). Figure 1 illustrates both the initial and current definition, and how P4 applies and adjusts to different clinical situations.

Whilst reducing unnecessary medical procedures, P4 lowers some specific costs of overall health expenditure, responding to one of the current worldwide governments' main objectives 9,10. When associated with equity policies, it can promote the principle of equity 11 , enabling access to prioritized and cost-effective procedures, impractical without P4 strategies, confirming its relevance for public health.

This paper aimed to report a bibliometric and descriptive content analysis on the concept of quaternary prevention (P4) in research published until August of 2018, and to prospectively correlate research trends. After a brief context we present the methods for data collection and analysis and its results, to later outline and discuss some research trends on P4. 


\section{PHYSICIAN'S ASSESSMENT}

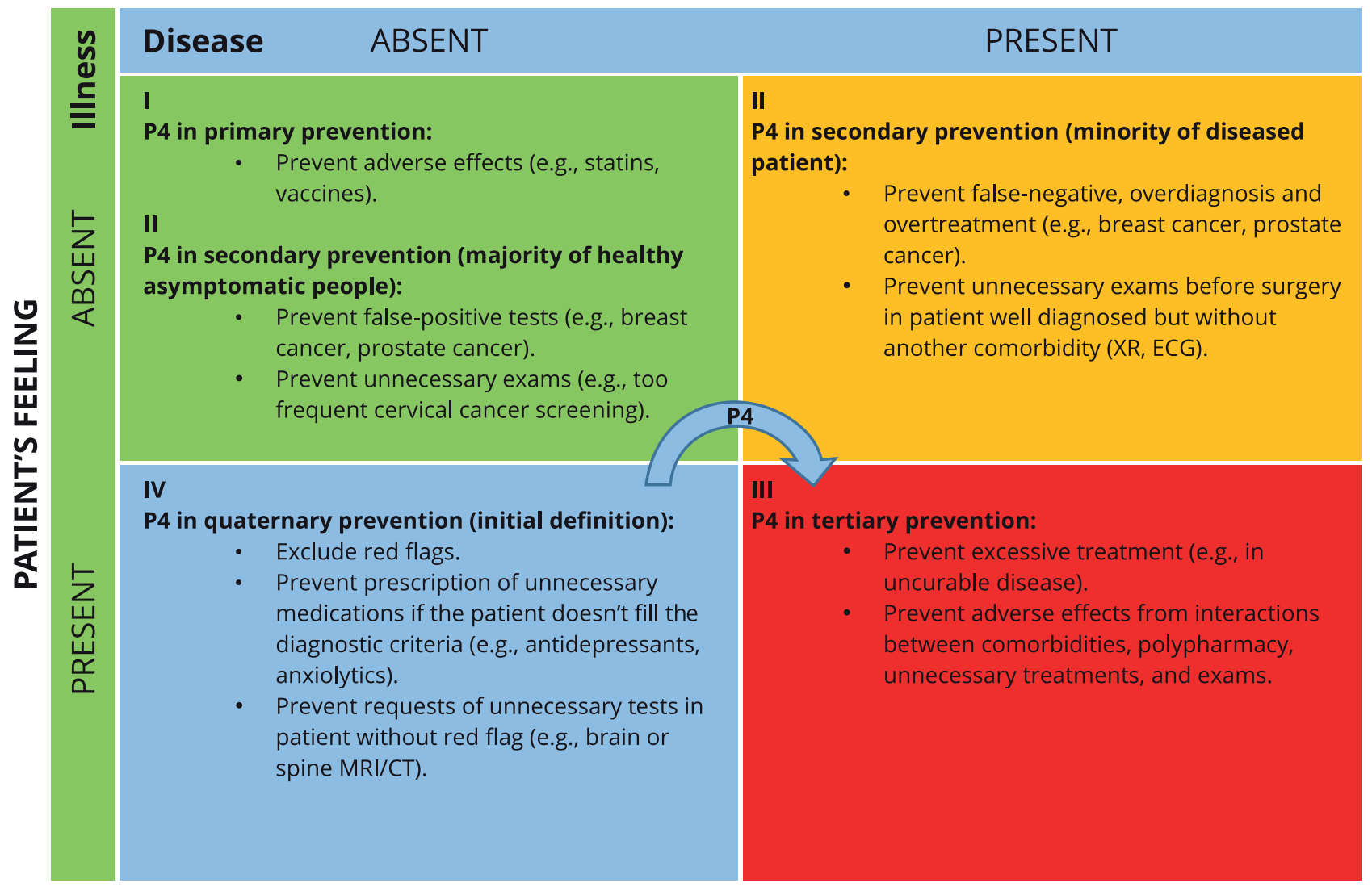

CT: computed tomography; ECG: electrocardiogram; MRI: magnetic resonance imaging; XR: X-ray.

Source: adapted from Jamoulle 28.

We hope to improve the global knowledge of P4 and further its understanding, highlighting authors, countries and journals involved in the research and publications on this topic, classifying the selected articles. In further papers, we intend to report a critical synthesis and in-depth analysis of the selected articles in a qualitative systematic review.

\section{Methods}

We used two complementary methods to achieve an integral assessment of research output on P4: a quantitative bibliometric approach - focused on measuring and evaluating research trends 12,13 - and a qualitative content analysis. Preliminary bibliometric research was already performed on medicalization during pregnancy 14 , overdiagnosis 15 - emphasizing breast cancer screening - and "unnecessary procedures" 16,17. None of them approaches P4, focusing instead on specific examples of overmedicalization or had significantly different objectives. The Cochrane Handbook for Systematic Reviews of Interventions 18 helped build the search strategy and the papers' selection process: "Evidence from qualitative studies can play an important role in adding value to systematic reviews for policy, practice 
and consumer decision-making" 19. Complementing the bibliometric approach, we performed a content analysis supported by the Standards for Reporting Qualitative Research (SRQR) 20.

\section{Criteria for article selection}

We included all scientific articles, published up until August 7th, 2018, from the research databases, available in Portuguese, English, Spanish, French and German, using the WICC's 2003 definition of P4. We excluded papers that employed synonyms like prevention of social damage, established complications of a specific disease, suffering or fall. We also removed studies and publications outside the genre and other records inconsistent with our inclusion criteria.

\section{Data and outcomes}

The collected data comprised: title; author's name and nationality; year of publication; name of the journal and country of its headquarters; language of the publication; methods; abstracts.

\section{Search methods}

We searched the PubMed, LILACS, SciELO and CINAHL databases. The Cochrane Library lacked records on $\mathrm{P} 4$, and thus was not included. To account for $\mathrm{P} 4$ being a recent concept in the literature, we used the widest search builder possible in all fields: using the conjunction "OR" coupled with a Medical Subject Headings (MeSH), when available.

PubMed, SciELO and CINAHL showed no pre-existing MeSH, requiring the search builder: ((“quaternary prevention”) OR “prevención cuaternaria”) OR “prevenção quaternária”. LILACS presented the descriptor (Health Sciences Descriptors - DeCS) "Quaternary Prevention”, expanded by: ((tw:(“prevenção quaternária”)) OR (tw:(“quaternary prevention”)) OR (tw:(“prevención cuaternaria”)) OR (mh:(“prevenção quaternária”)). A flow diagram created with Review Manager 5.3 (https:// training.cochrane.org/online-learning/core-software-cochrane-reviews/revman) illustrates the selection process (Figure 2).

\section{Data collection, analysis, and extraction}

The articles were exported to Zotero (https://www.zotero.org/), which made transferring information, removing duplicates and obtaining the initial bibliographic list faster. Results from electronic databases searches were reviewed to check the inclusion and exclusion criteria. We read the abstracts of the selected articles to check the P4 meaning, to later digitalize in Excel tables (https://products. office.com/). Unavailable articles were accessed through the website of the Brazilian Graduate Studies Coordinating Board (CAPES; http://www.periodicos.capes.gov.br/, accessed on 10/Nov/2019). We searched for the journal rank in the SCImago Journal \& Country Rank (https://www.scimagojr. com/journalrank.php, accessed on 10/Nov/2019) and Qualis/CAPES databases (Sucupira Platform. Qualis Periódicos. https://sucupira.capes.gov.br/sucupira/public/consultas/coleta/veiculoPublicacaoQualis/listaConsultaGeralPeriodicos.jsf, accessed on 17/Aug/2019), entering the results in the Excel tables.

\section{Bibliometric analysis}

For the bibliometric analysis, we built dynamic cross tables and outlined trends according to: year of publication, language of publication, name of the first authors and nationality, publications per capita - number of publications per first author's country/number of residents in million -, the country's population in 2019 - calculated by an estimation stem from the United Nations population estimates and projections (United Nations Population Division. https://population.un.org/wpp/DVD/Files/2_ Indicators\%20(Probabilistic\%20Projections)/UN_PPP2017_Output_PopTot.xls, accessed on 14/ Nov/2019) -, name of the journal and country of its headquarters, journal ranking (2017 SCImago: quartile Q1-Q5; 2013-2016 Qualis/CAPES: A1-C). 


\section{Figure 2}

Flowchart of the article selection process.

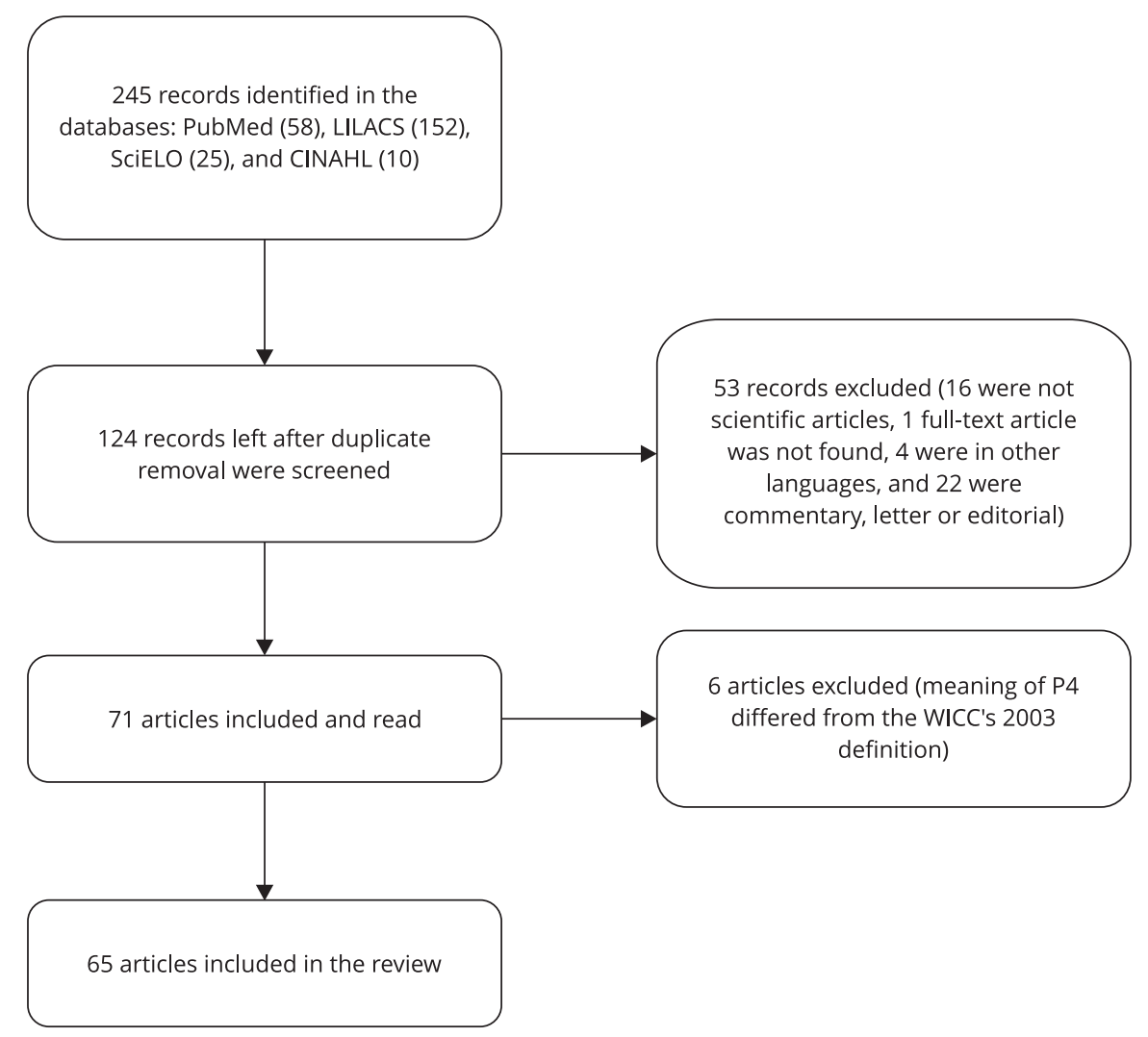

WICC: World International Classification Committee.

\section{Content analysis}

Focusing on the title and abstract, we categorized each paper according to its method - bibliographic research, qualitative research, quantitative research, case report - and we classified under one of the following categories:

(i) Epistemological and conceptual research focusing on P4 general concept and/or the overmedicalization process.

(ii) Studies addressing bioethical issues related to P4, in particular the non-maleficence and justice principles.

(iii) Reviews regarding empirical evidence on medical overuse and iatrogenesis, highlighting examples of overmedicalization (except screening).

(iv) Studies discussing screening, a type of potential iatrogenesis and one of the main focus of P4.

(v) Investigations outlining P4 implementation strategies and/or aiming to divulge the concept. 


\section{Results}

We identified 245 records in the electronic databases: 152 in LILACS, 58 in PubMed, 25 in SciELO and 10 in CINAHL. After removing duplicates $(\mathrm{n}=121), 124$ records remained. Later screening excluded one record because we could not find it, even after emailing journal and author, 16 because they were not scientific articles, four full-articles for being in other languages (three in Serbo-Croat and one in Korean) and 22 for not corresponding to the genre. We read the remaining 71 abstracts and excluded 6 more articles for using a different P4 definition than WICC (2003). Finally, the study included 65 articles (Figure 2).

\section{Bibliometric analysis}

The 65 selected articles were published between 2003 and 2018. Until 2011, less than one publication a year addressed P4, with the scientific output increasing from 2012 to 2014, and peaking in 2015 with 23 publications (35\% of the total number). Between 2016 and 2018 the number of publications was similar or slightly higher than the 2012-2014 period (Figure 3).

\section{Authors}

The first authors came from 17 different countries in Europe, South and North America and Asia. Brazilian authors responded for 15 papers (23\%), Spanish authors for 11 articles (17\%) and Portuguese authors for 8 publications (12\%) (Table 1). Considering the population size of each country, the ranking favored the smaller countries: Uruguay came in first (1.18), followed by Portugal (0.80), Belgium (0.36), Switzerland (0.24) and Spain (0.23), while Brazil (0.07) fell to the 7th position.

\section{Figure 3}

Articles per year of publication $(n=65)$.

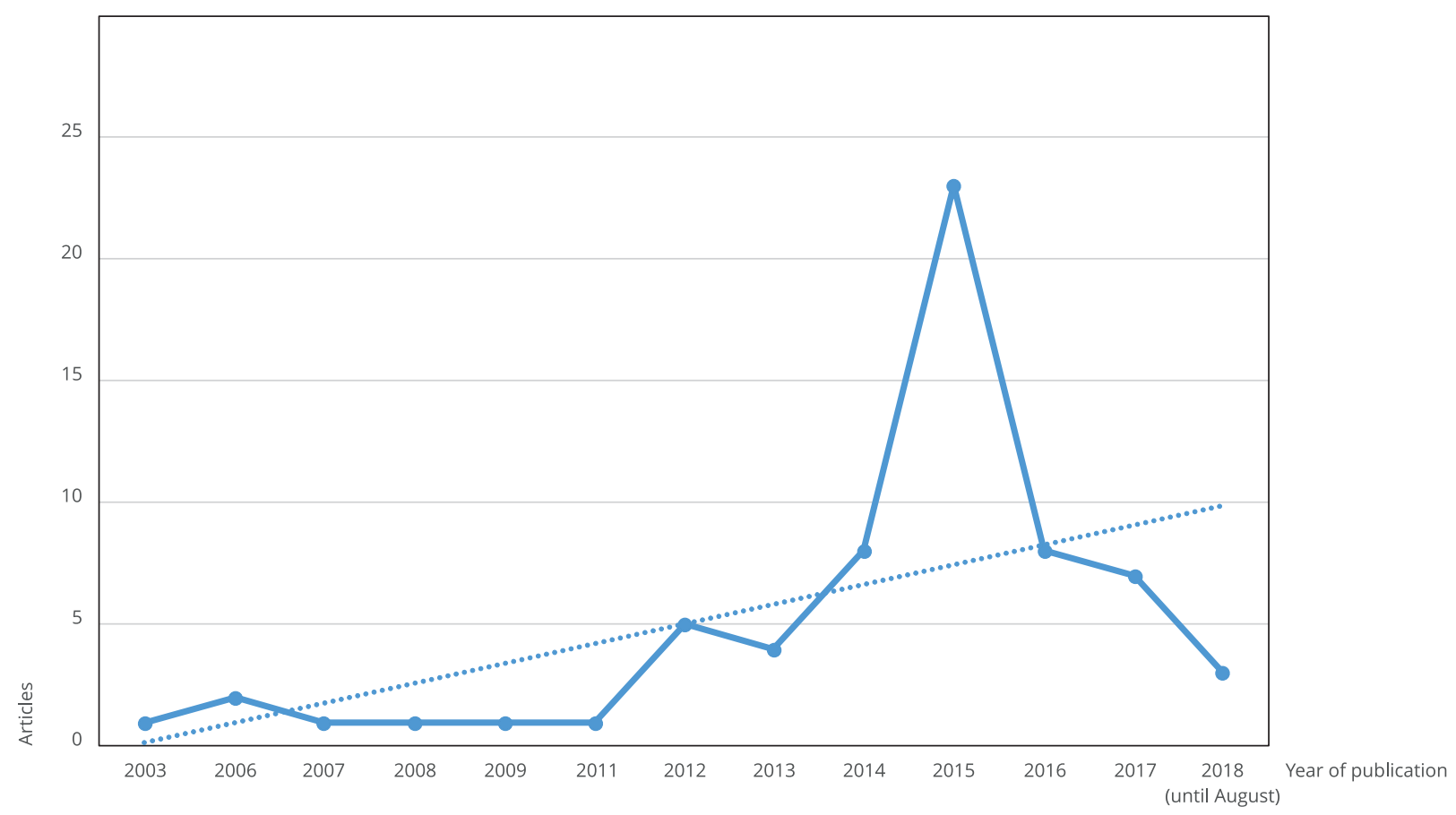


Table 1

Number of articles $(N=65)$ according to first author's nationality, year of publication and production per capita.

\begin{tabular}{|c|c|c|c|c|c|c|c|c|c|c|}
\hline Country & Until 2011 (included) & 2012 & 2013 & 2014 & 2015 & 2016 & 2017 & 2018 & Total & Production per capita (in millions) \\
\hline Brazil & 1 & 2 & & 4 & 3 & 2 & 2 & 1 & 15 & 0.07 \\
\hline Spain & 6 & 1 & 1 & 1 & 2 & & & & 11 & 0.23 \\
\hline Portugal & & 2 & 1 & 1 & 3 & & & 1 & 8 & 0.80 \\
\hline Argentina & & & & & 3 & & 2 & & 5 & 0.11 \\
\hline Belgium & & & & 1 & 3 & & & & 4 & 0.36 \\
\hline Uruguay & & & & & 2 & 1 & 1 & & 4 & 1.18 \\
\hline India & & & & & 1 & 2 & & & 3 & 0.00 \\
\hline France & & & & & 1 & & & 1 & 2 & 0.03 \\
\hline South Korea & & & & & 1 & 1 & & & 2 & 0.04 \\
\hline Switzerland & & & & 1 & 1 & & & & 2 & 0.24 \\
\hline Peru & & & & & & 1 & 1 & & 2 & 0.06 \\
\hline Canada & & & & & 2 & & & & 2 & 0.05 \\
\hline Germany & & & & & & & 1 & & 1 & 0.01 \\
\hline Vietnam & & & & & 1 & & & & 1 & 0.01 \\
\hline Norway & & & & & & 1 & & & 1 & 0.20 \\
\hline Bolivia & & & 1 & & & & & & 1 & 0.09 \\
\hline Italy & & & 1 & & & & & & 1 & 0.02 \\
\hline Total & 7 & 5 & 4 & 8 & 23 & 8 & 7 & 3 & 65 & 0.22 \\
\hline
\end{tabular}

Until 2011, six out of seven articles were written by Spanish authors, with three by Juán Gérvas 6,21,22, a family physician and retired professor who published more than 400 articles in scientific journals. Gérvas is an active proponent of P4 and wrote one of the most significant books on the topic: Healthy and Safe 23. Ibero-American academic movements, family physician association and researchers, such as Norman \& Tesser 24, based in Brazilian institutions, helped promote the concept in South America.

Until 2012, only Spanish, Brazilian, and Portuguese authors wrote about P4. Jamoulle and Tesser, established authors on the subject of P4, had six articles included here. Beyond Europe and South America, 11 out of 17 authors (65\%) came from Latin-speaking countries; Asian authors from South Korea, India, and Vietnam, as North American and Canadian authors, also took part in this process.

\section{Languages}

Considering the language, 40\% of the papers were published in English, 32\% in Portuguese, and 26\% in Spanish. Until 2011, the papers were written mainly by Spanish authors and published only in Spanish. Between 2012 and 2014, 88\% of the papers were in Spanish or Portuguese. In 2015, papers published in English increased significantly (60\% of the articles published in the same year), written by European, Asian, and South American authors. After 2015, the language distribution became more balanced.

\section{Journals}

We found published articles on P4 in 33 journals of 16 countries, with 9 Brazilian journals accounting for 33 published papers (51\% of all articles). The chronological and geographical expansion of the P4 publications according to the first author's nationality was similar to that of the journal's headquarter. P4 publications started in the South of Europe, spread to Brazil, then reached North America and Asia. 
Authors usually published in journals in their own country or from neighboring regions: Brazilian authors published 14/15 papers in Brazilian journals; Spanish authors published 9/11 articles in Spanish journals; Portuguese authors published 5/8 studies in Brazilian Journals; Argentinian authors published 4/5 papers in Argentinian journals; Uruguayan authors published 3/4 in Brazilian journals and Indian authors published 3/3 articles in a Pakistani journal.

The Revista Brasileira de Medicina de Família e Comunidade published 22 papers (34\% of all) between 2013 and 2016 - 10 in English (all in 2015), 8 in Portuguese, 4 in Spanish - and attracted authors from different nationalities (Argentina, Belgium, Brazil, Canada, France, Portugal, Spain, Switzerland, Uruguay, and Vietnam).

Most papers (49\% SCImago; 37\% Qualis/CAPES) pertained to journals outside the international rankings. Q1 or Q2 journals responded for 28\% of the published papers. Only French, German, Italian and Portuguese authors had a paper published in a Q1 journal: Monographs in Oral Science (Switzerland), BMC Family Practice (England), Archives of Gynecology and Obstetrics (Germany) and SpringerPlus (England).

The main Q2 journals were: Gaceta Sanitaria (Spain; 3 articles by Spanish first authors; all in Spanish), Cadernos de Saúde Pública (Brazil; 3 articles by Brazilian first authors; 2 in Portuguese and 1 in English) and Journal of Preventive Medicine and Public Health (South Korea; 2 articles by a South Korean first author; 2 papers in English). Publications in Q1 and Q2 journals are stable or slowly increasing, whereas publication in non-classified journals are decreasing significantly.

\section{Methods of the selected papers}

Most articles (88\%) used a bibliographic research as their main method. Case reports and qualitative research, each, appeared in 5\% of the papers (e.g., interviewing family physician about P4), while quantitative research appeared in one article (1\%).

\section{Main categories}

Regarding the distribution of the main approached topics, 16 articles (25\%) were placed in the conceptual category "general considerations about P4 and overmedicalization process". We classified many of the discussed aspects as: theoretical and conceptual aspects (prevention levels, evidence-based medicine (EBM), distinction between preventive approach and clinical care), medicalization drivers and consequences (conflict of interest, disease mongering, medicalization of risk factors, overdiagnosis and overtreatment) and protective factors (primary healthcare - PHC - attributes: longitudinality and role of gate-keeper; communication skills: doctor-patient relationship, patient-based medicine; Bioethics: non-maleficence and justice principles; and patient-safety strategies).

Only four articles (6\%) were classified in "Bioethics", addressing: the definition of health; the humanization of the doctor-patient relationship; the clinical context of uncertainty; political, economic and social determinants in health; autonomy, beneficence, non-maleficence and justice principles; intellectual freedom and responsibility; epistemology.

We classified 32 papers (49\%) under "specific examples of overmedicalization and iatrogenesis", including "screening": 31\% belonged to "specific iatrogenic situations", such as chronic diseases and polypharmacy, birth, mental health and others (odontology, geriatrics, pathology); 18\% belonged to the "screening" category (general aspects, cervical, breast and prostate cancers, genetic testing and neonatal screening).

And 13 articles (20\%) belonged to "P4 implementation and diffusion": four of them developed the humanization of health assistance and the major role of communication skills in reducing iatrogenic events. The other articles discussed medical prescription, strategies to ensure patient's safety, applicability of "Choosing Wisely" campaigns, manifestoes in favor of P4 and a medicine without conflict of interests, P4 teaching and search for P4 in electronic databases. 


\section{Discussion}

The P4 research output timeline starts just after the substantial publications of 2000 and 2002 on iatrogenesis: Is US Health Really the Best in the World? 7, The Arrogance of Preventive Medicine 25, and Too Much Medicine? 26; concept first discussed in Gérvas' 1997 paper reporting the inefficiency of statin treatment in primary prevention of ischemic cardiopathy 27 . In this context, the WICC accepted the concept of P4 in 2003, acknowledging its relevance and encouraging future publications. In the same year that Gérvas published the first article included in our review 6 .

The scientific output that followed increased slowly and progressively until its peak in 2015, as a probable response to P4 being one of the main subjects of the 21st WONCA World Conference 2016 in Rio de Janeiro (Figure 3). In the same year, Jamoulle led a specific edition of the Revista Brasileira de Medicina de Família e Comunidade 28 about P4 and the Ibero-American Family and Community Medicine Conference in Uruguay emphasized quaternary prevention. Those events significantly increased publications in English, and its geographical expansion. After 2015, the scientific output declined, returning to its baseline.

Until 2012, the first authors came from Spain, Portugal and Brazil, countries with a universal public health system and concerned about equity. The consolidation of Family Medicine in IberoAmerican countries, the development of the Ibero-American Family Medicine Confederation (CIMF) and the creation of the VI Ibero-American region of the WONCA in 2004 (https://www.semfyc.es/ la-medicina-de-familia/medicina-de-familia-internacional/organizaciones/cimf/, accessed on 19/ $\mathrm{Feb} / 2020$ ) may have sparkled research interests in family physicians and researchers of these regions. Uruguay, a country of 3,47 million people that organized the Ibero-American Family and Community Medicine Conference in 2015 and lead the WONCA group on P4 (Miguel Pizzanelli), reported first on the number of papers per capita.

Brazilian journals accept articles in many languages, which contributes to their predominance in the results. The Revista Brasileira de Medicina de Familia e Comunidade special edition on P4, the 2016 World WONCA Conference of Rio de Janeiro, and the publications of Norman \& Tesser 24 may also explain this prevalence. Public health policies in Brazil are another source of influence: in 2013, the Brazilian government launched, the More Doctors Program based on the principles of universality and equity, engaging more than 18,000 national and foreign physicians, allowing health access to 63 million Brazilians 29.

While Q1 and Q2 journals responded for 28\% of the published papers, non-classified journals held most of them. This result, however, is unrepresentative of the journals' quality, as Seglen 30 (p. 498) states:

(i) "Journal impact factors are determined by technicalities unrelated to the scientific quality of their articles";

(ii) "Journal impact factors depend on the research field: high impact factors are likely in journals covering large areas of basic research with a rapidly expanding but short lived literature that use many references per article".

Factors such as the language of publication can strongly impact the number of citations, affecting the journal impact factor and the visibility of the paper. Thus publish P4 papers in non-classified journals impairs its disclosure and its expansion. Publication costs also work in favor of publishing in low impact journals: most of the selected studies were conducted in low or middle-income countries, probably with little or no sponsorship.

Moreover, most online databases do not classify P4 as MeSH or other relevant keyword, which hinders its conceptual diffusion and scientific production, influencing its misrepresentation in online search databases.

To illustrate the factors mentioned above, the four publications in Q1 journals present four characteristics that facilitated their inclusion in the best classified journals: geographical placement (European authors in European journals), language of the publication (English), first authors nationality (France, Italy, and Portugal), and economic backgrounds.

Assessing the quality of the selected papers has been a quite difficult and sensitive task, especially because most of the articles were literature reviews, a type of study rarely uses a structured methodology 20 . While the papers frequently brought a broad conceptual understanding, includ- 
ing multidimensional analysis, they usually supported P4 thesis and seldom critically developed its potential weaknesses.

P4 is a complex concept based on historical, theoretical and scientific fundamentals involving several knowledge fields, suggesting the necessity of an exhaustive expertise in these areas. Previous understanding of these basics and their interconnections is essential to develop effective interventions tackling unnecessary medical procedures and their iatrogenic effects.

Developing the category "general considerations about P4 and overmedicalization process" becomes urgent, in this scenario. The overmedicalization process results from biased studies, conflict of interest and disease mongering strategies involving the pharmaceutical industry and physicians 1 . The rising number of ad campaigns enhanced this phenomenon, infusing the population with fabricated health concerns and expectations regarding the health care system. Concerning the definition of P4, the authors wrote it generally just after the first three levels of prevention of Leavell \& Clark 4 .

P4 constitutes a counter-hegemonic concept, approaching modern and occidental medicine in a critical and multidimensional perspective; actual biomedical research, regardless of its funding 31,32, focuses on high-technology studies 33 and neglects medical overuse issues. This explains why the vast majority of the included papers were bibliographic research and low-cost studies.

While bibliographic studies helped stablish the robust theoretic base of such a recent and interdisciplinary concept, qualitative studies promote the identification and analysis of key elements involved in medical overuse process, such as health actors' perception and practice. These are indispensable to create effective strategies to significantly change health practice and impact medical overuse, but are very time-consuming and high cost.

Quantitative research accounted for one paper, probably because it is generally used to evidence medical intervention efficacy, not its harm. The included study 34 highlighted significant data on overscreening and underscreening for cervical cancer in a specific population. This type of study is brief, low-cost, and extremely relevant, because it reveals precise quantitative estimations about overmedicalization procedures, including the saved expenditure by using a P4 approach. Case-report studies can also improve theoretical aspects but contribute less in creating strategies to impact overmedicalization due to analyzing a singular and practical example.

In a context where medicine is inducing medical overuse, leading to an outbreak of iatrogenic events 7 and opposing medicine principles, several papers approached this issue in an ethical perspective. Key point of the P4 problematic, the ethical perspective considers the risk and benefits of each clinical decision, integrating critical reflections on beneficence and non-maleficence principle into health practice. A broad theoretical knowledge, accurate competence to critically assess available evidence and a global understanding of each clinical case are required to apply such type of practice.

The second point focuses on the autonomy principle since the patient always takes part in the clinical decision-making. In some situations, its role gains significance, as in shared decisions; advertisements minimizing the risks of medical intervention (e.g., PSA screening ${ }^{35}$ ) and concealing the prevalence of severe iatrogenic damages also affects the patient's opinion. The role of P4 is to identify possible bias in the free and informed patient decision-making, and build strategies to face or prevent them.

P4 also aims to tackle medical overuse to promote equity, reallocating resources to necessary medical interventions. In this category, the papers assessed knowledge (epistemology) and ethics (non-maleficence and beneficence principles); analyzed specific bioethical challenges regarding "incidentalomas" 36; outlined schemes, considering cross-sectoral engagement, including multiple dimensions, to recover the principles of a human-centered medicine 37; others wrote on the practitioners' responsibility 38. One of the few criticisms made, suggested that P4 "needs to be theoretically clarified and more widespread among - and dialogued with - health professionals of various specialties" 39 (p. 1485); it must surpass medical practice and become an interdisciplinary practice.

The papers classified as "specific iatrogenic examples" addressed some specific population groups and criticized the medicalization of healthy people or physiological situations, emphasizing the frequent iatrogenic results. A paper about pregnancy showed how health professionals usually handled it as a disease, especially the labour 40 . Tesser et al. ${ }^{41}$ reported the excess of episiotomy, cesarean section and routine use of oxytocin in Brasil, suggesting PHC-centered P4 strategies. 
Similarly, mental health represents a field whose epistemology, practice and results are frequently questioned ${ }^{42}$. The selected papers of this topic criticize the treatment of healthy people, as well as the biological reductionist theories used to explain mental health problems, ruling out key elements such as social dimensions. Older adults also constitutes a vulnerable group to iatrogenesis, due to: polymorbidity and polypharmacy, lower metabolism rate, cerebral and other functions degeneration, shorter life expectancy. In all these specific groups or situations, P4 suggests using "watchful waiting" and "de-prescribing" harmful medications and heavy treatments. To do so, health professionals need a good knowledge on EBM to critically approach the available evidence, adapting to every individual situation. The other articles on odontology, pathology, chronic diseases developed similar reflections, reporting discrepancies between the excess of medical procedures, the cost-effectiveness, and the non-maleficence principle.

Screening belongs to the second level of prevention, aiming to detect asymptomatic diseases and treat them early. Screening procedures are crucial when the risk/benefit balance unequivocally favors the patient. This differs completely from curative situations, where the patient has a disease and suffers; which allows a thinner margin between risks and benefits, because if we do not act, the clinical outcomes are much worse than if we do 21 . Thus, more research must evaluate the harm of screening connected with other type of iatrogenesis that affect healthy people, like primary prevention.

Papers in the "implementation and divulgation strategies of P4" category proposed strategies regarding the drivers of medical overuse, focusing on: physicians, patients, pharmaceutical industry, politicians and the means of communication between them. Improving the communication abilities of the physicians, for example, through a patient-centered approach 43 was one of the most $\mathrm{P} 4$ suggested strategies. This approach involves: showing empathy, constructing a trustworthy therapeutic relationship, exploring the illness, identifying the patient's stress-factors and sharing decision-making.

All these communication skills effectively improved mental health, reduced health system overuse and improved symptoms. Patient-centered medicine appears, thus, as a key element in tackling medical overuse and reducing unnecessary medical procedures. Another significant and complementary perspective focuses on clinicians, inviting them to enhance their critical skills to assess clinical guidelines, encouraging the use a watchful waiting approach to avoid overmedicalization.

One of the selected papers 44 mentioned the "Choosing Wisely" campaign, launched by the American Board of Internal Medicine in 201245 which created and disclosed a list of five unnecessary medical procedures to be avoided and encouraged other medical societies to do the same. This type of strategy showed evidences of cost-effectiveness in multiple studies 46 . Another suggested strategy was to establish a medicine without conflict of interests that biases most scientific studies and strongly impacts guidelines.

\section{Strengths and weaknesses of the study}

The present study is the first bibliometric and descriptive content analysis on P4. While some bibliometric studies about adjacent topics such as medicalization 14, overdiagnosis 15 or "unnecessary procedures" 16 exist, their objectives focused on specific clinical situations and not on discussing P4.

We employed a systematic methodology and used internationally acknowledged databases with minimal restriction criteria, which positively supports our results reliability. However, several key articles escaped our selection: one by Jamoulle 3 and two articles by Starfield, Gérvas, Heath, and collaborators 47,48 could have helped our analysis, but did not match our search terms. This highlights the problems of $\mathrm{P} 4$ search, related to its absence from the MeSH or keywords in major databases. The language criteria excluded other four articles.

The decision to consider only the first authors data to perform the statistical results, resulting from our focus on a strong methodology, probably resulted in an overall reduction of the authors nationalities.

Journal ranking did not represent the most significant factor to assess the publications 49 , but it is one of the few tools that can assess and, maybe, roughly explain the visibility - not the quality - of some scientific studies in the world. It could also explain and highlight journals and countries inequalities according to research output. 
Most selected articles were bibliographic studies, which provide interesting data with conceptual or historical aspects that help establish a robust background. On the other hand, the studies were frequently non-systematized and lacked a critical approach on the topic.

Several articles approached more than one category hindering their classification. Aiming at a global view on research output, we decided to classify each included paper under a single category following the main objective of the article. As a qualitative classification, any bias according to the coder subjective decision could occur.

\section{Practical implication}

P4 represents a relevant concept for public health as it promotes the identification and prevention of potential iatrogenic situations, reducing overall iatrogenic mortality and health costs. The papers suggest concrete policies, such as cross-sectoral collaboration (political, legal, social, educational and sanitary), P4 teaching in health graduation and post-graduation programs, improving the critical approach of clinical studies and guidelines, practical changes in the medical prescription and appropriate use of communication skills.

\section{Research implications}

P4 constitutes a critical approach on modern medicine, exposing most of its limitations, and represents a counter-hegemonic concept. While we observed a significant increase in the scientific production in 2015, the number of publications decreased after this "golden year". We consider that research to further the categories developed in this study is required, prioritizing:

(i) Quantitative studies on medical overuse, evaluating the iatrogenic outcomes of medical intervention (e.g., primary and secondary prevention interventions) on previously healthy people;

(ii) Bibliographic research and qualitative studies identifying factors that lead to medical overuse and developing P4 strategies;

(iii) Studies assessing the impact of P4 strategies (e.g., communication skills teaching, critical approach on EBM, disclosure of the physician's conflict of interests) on clinical outcomes (mortality, iatrogenic events, cost-effectiveness, patient, and physician's perceptions);

(iv) Studies and interventions evaluating health promotion (e.g., physical activity, nutritional, stress management, social inclusion measures) and/or health education (e.g., population education about P4), without medical interventions and analyzing the outcomes (e.g., mortality, cost-effectiveness, patient, and physician's perceptions).

The total number of articles remains low if compared to other search terms such as "medical overuse", which returns 100 times more results than "quaternary prevention" in PubMed. As a linguistic and conceptual gap could explain this consistent difference, we suggest a few strategies, involving linguistic, conceptual, information and communication technologies dimensions:

(i) To insist on the English language to promote P4 publications worldwide;

(ii) To disclose the concept and clarify possible misunderstandings regarding its initial and current definition;

(iii) To take up other adjacent and more "famous" concepts, such as "medical overuse", "overdiagnosis" or even "overtreatment", putting them in the abstracts and as keywords;

(iv) To publish more often in Q1 or Q2 journals and, when possible, addressing quantitative studies that support P4 (e. g., cost-effectiveness and mortality reduction);

(v) To claim the inclusion of $\mathrm{P} 4$ as a MeSH in the international databases. 


\section{Conclusion}

The present bibliometric and content analysis highlighted key elements that affect the research output on P4: conceptual, geographical, linguistic, WONCA conferences and model of healthcare systems in the authors' country. Most of the included papers used a bibliographic research method and approached equally the causes, the examples of overmedicalization and the implementation strategies. Quaternary prevention represents an ethical fight towards fair and equal access to health services. Despite limited quality and quantity of available studies on the topic, P4 and its scientific output are relevant for public health. Further studies are recommended, especially to assess its effectiveness to prevent iatrogenic outbreak and lower global health expenditure.

\section{Contributors}

M. A. Depallens contributed to the study design, led the selection of the articles, extraction and classification of the data and preliminary analysis, contributed to the preliminary interpretation and the final draft. J. M. M. Guimarães and N. Almeida Filho contributed to the study design, the preliminary interpretation and the final draft.

\section{References}

1. Gøtzsche PC. Deadly medicines and organised crime: how Big Pharma has corrupted healthcare. London: Radcliffe Publishing; 2013.

2. Illich I. Medical nemesis. The expropriation of health. New York: Pantheon Books; 1976.

3. Jamoulle M. Information et informatisation en médecine générale. In: Berleur J, Labet-Maris CL, Poswick RF, Valenduc G, Van Bastelaer P, editors. Les informagiciens. Namur: Presses Universitaires de Namur; 1986. p. 193-209.

4. Leavell HD, Clark EG, editors. Preventive medicine for the doctor in his community: an epidemiologic approach. 3rd Ed. New York: McGraw-Hill; 1960.

5. Kleinman A. The illness narratives: suffering, healing \& the human condition. New York: Basic Books; 1988.

6. Gérvas J, Pérez Fernández MP. Genética y prevención cuaternaria. El ejemplo de la hemochromatosis. Aten Primaria 2003; 32:158-62.

7. Starfield B. Is US health really the best in the world? JAMA 2000; 284:483-5.

8. WONCA International Classification Committee. Wonca international dictionary for general/family practice. http://www.ph3c. org/ph3c/docs/27/000092/0000052.pdf (accessed on $26 / \mathrm{Feb} / 2020$ ).

9. World Health Organization. The World Health Report. Health systems financing: the path to universal coverage. Geneva: World Health Organization; 2010.

\section{Additional informations}

ORCID: Miguel Andino Depallens (0000-00016499-8437); Jane Mary de Medeiros Guimarães (0000-0002-9538-2675); Naomar Almeida Filho (0000-0002-4435-755X).

10. World Health Organization. New perspectives on global health spending for universal health coverage. Geneva: World Health Organization; 2018.

11. World Organization of National Colleges, Academies and Academic Associations of General Practitioners/Family Physicians. WONCA Special Interest Group: quaternary prevention \& overmedicalization. https://www.glo balfamilydoctor.com/groups/SpecialInterest Groups/QuaternaryPrevention.aspx (accessed on 06/Jan/2020).

12. Narin F, Olivastro D, Stevens K. Bibliometrics theory, practice, and problems. Eval Rev 1994; 18:65-76.

13. Pendlebury DA. White paper using bibliometrics in evaluating research. Philadelphia: Thomson Reuters; 2010.

14. Marcellus L. Bibliometric and textual analysis of historical patterns in maternal-infant health and nursing issues in the Canadian NurseJournal, 1905-2015. Can J Nurs Res 2019; 51:5362.

15. Rasmussen K, Jørgensen KJ, Gøtzsche PC. Citations of scientific results and conflicts of interest: the case of mammography screening. BMJ Evid Based Med 2013; 18:83-9. 
16. Bunn F, Trivedi D, Alderson P, Hamilton L, Martin A, Pinkney E, et al. The impact of Cochrane Reviews: a mixed-methods evaluation of outputs from Cochrane Review Groups supported by the National Institute for Health Research. Health Technol Assess 2015; 19:199, v-vi.

17. Bunn F, Trivedi D, Alderson P, Hamilton L, Martin A, Iliffe S. The impact of Cochrane Reviews: a mixed-methods evaluation of outputs from Cochrane Review Groups supported by the National Institute for Health Research. Syst Rev 2014; 3:125.

18. Higgins JPT, Green S, editors. Cochrane handbook for systematic reviews of interventions. Version 5.1.0. The Cochrane Collaboration; 2011. https://www.cochrane-handbook.org.

19. Noyes J, Popay J, Pearson A, Hannes K, Booth A. Chapter 20: qualitative research and Cochrane reviews. In: Higgins JPT, Green S, editors. Cochrane handbook for systematic reviews of interventions. Version 5.1.0. The Cochrane Collaboration; 2011. https://www. cochrane-handbook.org.

20. O’Brien BC, Harris IB, Beckman TJ, Reed DA, Cook DA. Standards for reporting qualitative research: a synthesis of recommendations. Acad Med 2014; 89:1245-51.

21. Gérvas J, Pérez Fernández M. Limits to the power of medicine to define disease and risk factor, and quaternary prevention. Gac Sanit 2006; 20 Suppl 3:66-71.

22. Gérvas J. Diagnostic and therapeutic activity moderation. Quaternary and genetic prevention. Gac Sanit 2006; 20 Suppl 1:127-34.

23. Gérvas J, Pérez Fernández M. Sano y salvo (y libres de intervenciones médicas innecesarias). Barcelona: Los Libros del Lince; 2013.

24. Norman AH, Tesser CD. Prevenção quaternária na atenção primária à saúde: uma necessidade do Sistema Único de Saúde. Cad Saúde Pública 2009; 25:2012-20.

25. Sackett DL. The arrogance of preventive medicine. CMAJ 2002; 167:363-4.

26. Moynihan R, Smith R. Too much medicine? BMJ 2002; 324:859-60.

27. Gérvas J, Pérez Fernández M. Las hiperlipemias y la prevención primaria de la cardiopatía isquémica. Med Clin (Barc) 1997; 109:549-52.

28. Jamoulle M. Prevenção quaternária: primeiro não causar dano. Rev Bras Med Fam Comumidade 2015; 10:1-3.

29. Departamento de Planejamento e Regulação da Provisão de Profissionais de Saúde, Secretaria de Gestão do Trabalho e da Educação na Saúde, Ministério da Saúde. Programa Mais Médicos. Brasília: Ministério da Saúde; 2017.

30. Seglen PO. Why the impact factor of journals should not be used for evaluating research. BMJ 1997; 314:498-502.

31. Dorsey ER, de Roulet J, Thompson JP, Reminick JI, Thai A, White-Stellato Z, et al. Funding of US biomedical research, 2003-2008. JAMA 2010; 303:137-43.
32. Institute of Medicine. Strategies to leverage research funding: guiding DOD's peer reviewed medical research programs. Washington DC: National Academies Press; 2004.

33. Owens B. Mapping biomedical research in the USA. Lancet 2014; 384:11-4.

34. Cardozo Rufo V, Fernández Saavedra ML. Tamizaje de cáncer de cuello de útero en usuarias de la Policlínica Villa Ferré (Uruguay). Una mirada desde la prevención cuaternaria. Archiv Med Fam Gen 2017; 14:7-13.

35. Modesto AAD, Lima RLB, D'Angelis AC, Augusto $\mathrm{DK}$. Um novembro não tão azul: debatendo rastreamento de câncer de próstata e saúde do homem. Interface (Botucatu) 2018; 22:251-62.

36. Mariño MA. Incidentalomas: concept, relevance and challenges for medical practice. Rev Bras Med Fam Comunidade 2015; 10:1-9.

37. La Valle R. Sobre la definición de salud. Archiv Med Fam Gen 2017; 14:27-31.

38. Widmer D. Philosophical roots of quaternary prevention. Rev Bras Med Fam Comunidade 2015; 10:1-8.

39. Oliveira CC, Reis A. Questões epistemológicas e bioéticas da prevenção quaternária. Physis (Rio J.) 2012; 22:1485-502.

40. Souza JP, Pileggi-Castro C. On labor and childbirth: the importance of quaternary prevention. Cad Saúde Pública 2014; 30 Suppl $1: \mathrm{S} 1-3$.

41. Tesser CD, Knobel R, Andrezzo HFA, Diniz SG. Violência obstétrica e prevenção quaternária: o que é e o que fazer. Rev Bras Med Fam Comunidade 2015; 10:1-12.

42. Whitaker R. Anatomy of an epidemic. New York: Crown Publishers; 2010.

43. Stewart M, Brown JB, Weston WW, McWhinney IR, McWilliam CL, Freeman TR. Patientcentered medicine: transforming the clinical method. Oxford: Radcliffe Mecial Press; 2003.

44. Cuba Fuentes MS, Zegarra Zamalloa CO, Reichert S, Gill D. Attitudes, perceptions, and awareness concerning quaternary prevention among family doctors working in the Social Security System, Peru: a cross-sectional descriptive study. Medwave 2016; 16:e6433.

45. Choosing Wisely. History. https://www. choosingwisely.org/our-mission/history/ (accessed on 26/Nov/2019).

46. Choosing Wisely. Does Choosing Wisely work? https://www.choosingwisely.org/get ting-started/resource-library/does-choosingwisely-work/ (accesssed on 10/Nov/2019).

47. Starfield B, Hyde J, Gérvas J, Heath I. The concept of prevention: a good idea gone astray? J Epidemiol Community Health 2008; 62:580-3.

48. Gérvas J, Starfield B, Heath I. Is clinical prevention better than cure? Lancet 2008; 372:1997-9.

49. Time to remodel the journal impact factor. Nature 2016; 535:466. 


\section{Resumo}

De acordo com a Organização Mundial de Médicos de Família (WONCA), a prevenção quaternária (P4) é um conceito recente que procura prevenir a utilização excessiva de procedimentos médicos. O estudo teve como objetivos, medir e mapear a produção de pesquisas sobre a P4, bem como as suas tendências e avaliar a sua situação internacional por meio de uma análise bibliométrica e análise descritiva de conteúdo. Os autores realizaram uma revisão de artigos científicos sobre a P4, registrados nas bases de dados PubMed, LILACS, SciELO e CINAHL. As principais variáveis foram: ano de publicação, nome e nacionalidade do primeiro autor, nome da revista, país e ranking, idioma de publicação, métodos utilizados e principais temas abordados. Foram incluidos 65 artigos, publicados em 33 revistas de 16 países entre 2003 e 2018, com um pico nas publicações em 2015. Os primeiros autores vinham de 17 paises diferentes; 23\% desses autores eram brasileiros, $e$ o Uruguai foi o país com a maior produção científica per capita sobre P4. Vinte e oito por cento dos artigos foram publicados em periódicos Q1 ou Q2, $88 \%$ dos artigos tratavam de buscas bibliográficas e 38\% focavam em exemplos específicos de uso excessivo de procedimentos médicos. A P4 representa uma abordagem ética e válida para prevenir a ocorrência de eventos iatrogênicos e alcançar acesso equânime e justo aos serviços de saúde. Os fatores fundamentais que afetaram a produção de pesquisa sobre a P4 foram os elementos conceituais, geográficos e linguísticos, além das conferências da WONCA e o tipo de sistema de saúde no país do autor. Ainda há limitações na qualidade e na quantidade dos estudos disponiveis, portanto são recomendados estudos adicionais para avaliar o impacto efetivo da P4 sobre a saúde pública.

Prevenção Quaternária; Sobremedicalização; Bibliometria; Pesquisa Qualitativa

\section{Resumen}

Según la Organización Mundial de los Médicos de Familia (WONCA), la prevención cuaternaria $(P 4)$ es un concepto reciente que tiene como fin prevenir el uso excesivo de los procedimientos médicos. En este sentido, los objetivos de este estudio fueron medir y mapear las investigaciones con respecto a la P4, así como señalar sus tendencias y evaluar su estatus internacional actual por médio de un análisis bibliométrico y de contenido descriptivo. Revisamos artículos científicos sobre $P 4$ registrados en PubMed, LILACS, SciELO o CINAHL. Las variables principales fueron: año de publicación, nombre del autor y nacionalidad, nombre de la publicación, país y ranking, idioma de publicación, métodos usados y temas principales abordados. Se incluyeron 65 artículos, presentes en 33 revistas de 16 países entre 2003 y 2018, con un pico de publicaciones en 2015. Los primeros autores venían de 17 países diferentes, un $23 \%$ de ellos eran brasileños y Uruguay fue la nación líder según la producción científica per cápita. Un 28\% de los artículos fueron publicados en revistas Q1 o Q2. Un $88 \%$ de los artículos eran de investigación bibliográfica y un $38 \%$ de entre todos estaban enfocados a ejemplos específicos de uso abusivo de procedimientos médicos. La P4 representa un enfoque ético y válido para prevenir la ocurrencia de eventos iatrogénicos, así como para alcanzar el acceso ecuánime y justo a los servicios de salud. Elementos conceptuales, geográficos y lingüísticos, así como conferencias WONCA y tipo de sistemas de salud en los países de los autores fueron factores fundamentales que afectaron a la producción científica. La calidad y cantidad de estudios disponibles es todavía limitada, por lo tanto se recomienda realizar investigaciones adicionales para evaluar el impacto efectivo de la P4 sobre la salud pública.

Prevención Cuaternaria; Uso Excesivo de los Servicios de Salud; Bibliometría; Investigación Cualitativa
Submitted on 09/Dec/2019

Final version resubmitted on 27/Feb/2020

Approved on 23/Apr/2020 